\title{
Specific Oxygen Reaction through analysis of Malondialdehyde in the body of Methapire postuma
}

\author{
Widowati Budijastuti ${ }^{1}$, Nur Ducha ${ }^{2}$, Dyah Hariyani, Sunu Kuntjoro \\ Biology Department \\ Universitas Negeri Surabaya \\ Surabaya, Indonesia \\ ${ }^{1}$ widowatibudijastuti@unesa.ac.id, ${ }^{2}$ nurducha@unesa.ac.id
}

\begin{abstract}
The purpose of this study was to evaluate the specific oxygen reaction on the body of Methapire postuma worms found in $\mathrm{Pb}$ metal contaminated areas. This study uses exploration methods with selected samples in Bangkalan. The body of the worm was cut off on the spermateka, vesicles and prostate sections and then analyzed for the Malondialdehyde content of each body part and analyzed for metal $\mathrm{Pb}$ soil. The results of the data were relationship analyzed by Pearson and showed that there was a relationship of $\mathrm{Pb}$ heavy metals to the MDA content in the spermateka part. But there was no correlation between $\mathrm{Pb}$ heavy metal and MDA content in the vesicles and prostate. The conclusion of this study is the highest evaluation of specific oxygen reaction analysis on the body of Methapire postuma worms occurs in the prostate.
\end{abstract}

Keywords-specific oxygen reaction; malondialdehyde; methaphire postuma

\section{I.INTRODUCTION}

Methapire postuma worm is a worm from the Megascolexsidae family that has morphology Dark brown color, rolled body, length 60-140, diameter 3-8 mm, open prostomium epilobus or tanylobus, first dorsal hole in the 12/13 segment, and 20-140, anular clitellum segmented 14-16, there is setae or not in clitellum. Male holes present in sperm anatomy at 5/6/7/8/9, small Spermateka in segment 6-9, marker genital parallel to male hole, single dorsal blood vessel, heart in segment to 7,8,9, gizzard on segment to 8, simple type typhosol. The prostate is in the form of recemosa. [1]. This worm is found in high Pb-heavy soil in Bangkalan [2].

Based on the literature this worm has resistance to heavy metals so that it can be said as a heavy metal bioindicator [3], capable of being a waste processor or vermicomposting (4) and even vermiremidiasi [5]. This shows that worms are able to tolerate heavy metals in their body or resistance. Heavy metals can enter the body through metallothionein and then metallothionein bonds with metals will damage the body's cells by carrying out oxidative stress. If there is accumulation of heavy metals and cause oxidative stress, the cells undergo apoptosis and tissue damage. There is a relationship between oxidative stress and vascular complications because oxidative stress can cause lipid peroxidation which results in damage to the cell membrane in organs in the body of the worm [6], [7]. For this reason, it is necessary to evaluate which body parts have an effect on $\mathrm{Pb}$ heavy metals, especially on Metaphire postuma worms which are known as heavy metal bioindicators, and vermicomposting. This research can be useful as a benchmark for heavy metal toxicity, especially in earthworms and find out the analysis of Malondialdehyde as a measure of oxidative stress in earthworms.

\section{II.RESEARCH METHODS}

\section{A. Type of Research}

This study was an observational study in which sampling was taken to evaluate the ROS reaction of spermateka, Metaphire postuma vesicles and prostates in Bangkalan Madura. With 4 stations namely Kamal, Labangkamal, By Pass and Burneh. In these four stations, soil $\mathrm{Pb}$ heavy metals were analyzed and analysis of Malondialdehyde on the spermateka, vesicles and prostate worms.

\section{B. Procedure}

The study consisted of four processes, namely earthworm sampling procedures, soil heavy metal measurement procedures, identification of earthworm species and analysis of tissue damage through analysis of Malondialdehyde (MDA).

\section{MDA Analysis Procedure}

The principle of MDA analysis is that the heating will hydrolyze lipid peroxide so that the bound MDA will be released and will react with TBA in an acidic atmosphere to form the red MDA-TBA complex. The intensity of the red color can be measured at a wavelength of $532 \mathrm{~nm}$.

\section{Data analysis}

Data of test results of heavy metal content of soil $\mathrm{Pb}$ and MDA content on spermateka body, vesicles and prostate worms were tested statistically using Spearman test. 


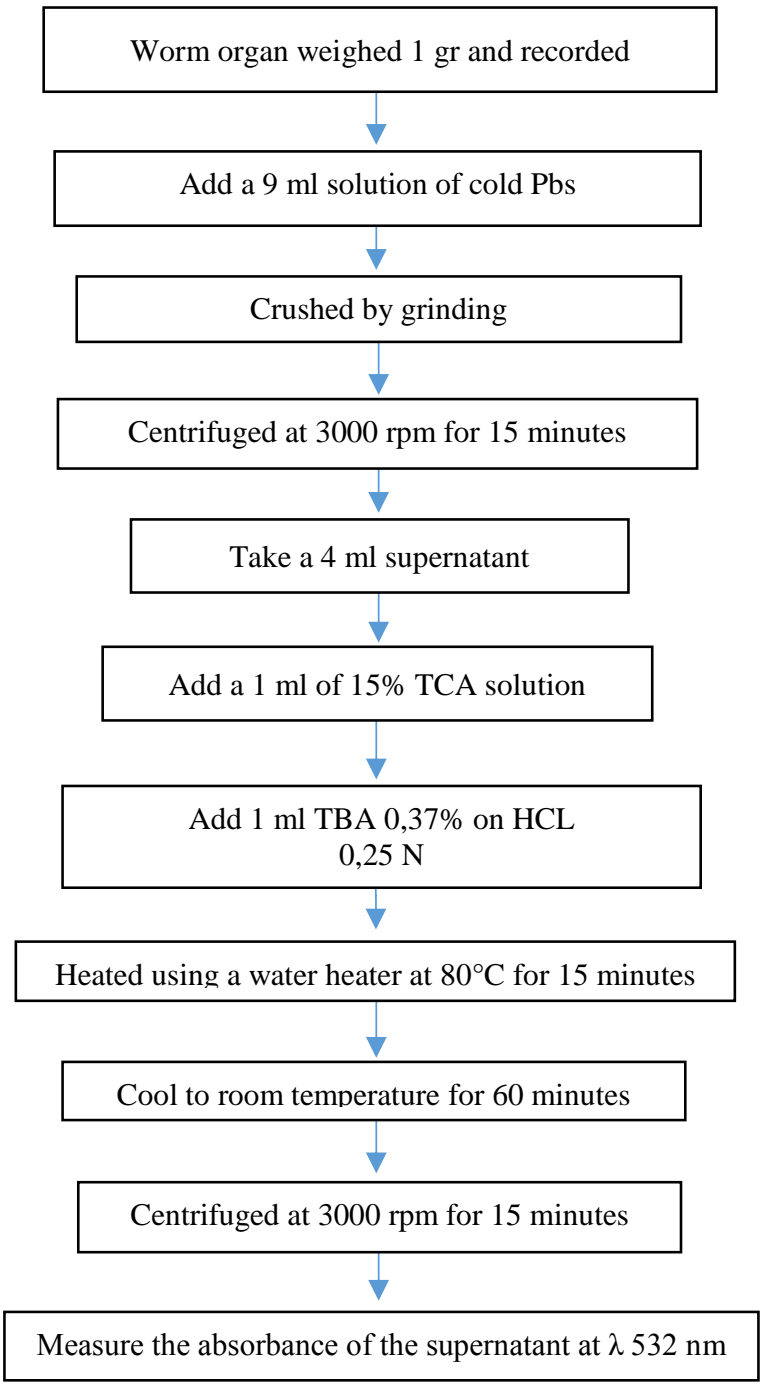

Fig. 1. Research Procedure

\section{RESULTS AND DISCUSSION}

The results of research on $\mathrm{Pb}$ heavy metals in the soil and the average value of MDA in the three body parts of worms in 4 locations can be seen in Table I below.

TABLE I. RElationship Average VAlue of HeAvy Metal CONTENT PB OF SOIL AND AVERAGE VALUE OF MDA

\begin{tabular}{|c|c|c|c|c|}
\hline Area & $\begin{array}{c}\text { Heavy } \\
\text { Metal } \\
\text { Pb } \\
\text { (mg.kg-1 } \\
\pm \text { SD) }\end{array}$ & $\begin{array}{c}\text { MDA on } \\
\text { spermateka } \\
\text { (nmol.ml }^{-1} \pm \\
\text { SD) }\end{array}$ & $\begin{array}{c}\begin{array}{c}\text { MDA } \\
\text { onvesikula } \\
\text { (nmol.ml- }^{-1} \pm \\
\text { SD) }\end{array}\end{array}$ & $\begin{array}{c}\text { MDA on } \\
\text { prostat } \\
(\text { nmol.ml } \\
{ }_{ \pm \pm \text {SD }}\end{array}$ \\
\hline Kamal & $\begin{array}{c}110.40 \pm \\
106.65\end{array}$ & $15.53 \pm 5.62$ & $12.27 \pm 1.02$ & $7.94 \pm 0$ \\
\hline $\begin{array}{c}\text { Labang } \\
\text { Kamal }\end{array}$ & $\begin{array}{c}48.89 \pm \\
46,81\end{array}$ & $8.66 \pm 1.02$ & $16.25 \pm 4.60$ & $7.94 \pm 0$ \\
\hline Burneh & $\begin{array}{c}79.07 \pm \\
82.05\end{array}$ & $7.94 \pm 0$ & $11.55 \pm 0$ & $7.94 \pm 0$ \\
\hline By Pass & $\begin{array}{l}66.31 \pm \\
57.62\end{array}$ & $10.47 \pm 1.53$ & $8.30 \pm 0.51$ & $7.94 \pm 0$ \\
\hline
\end{tabular}

Pearson's analysis of the relationship between $\mathrm{Pb}$ heavy metal content and MDA value has a significant relationship with MDA content values in the spermatic body with a value of 0.024 (less than 0.05 ) but the heavy metal $\mathrm{Pb}$ relationship is not significant in the MDA values in vesicles and prostate. It was concluded that the higher the $\mathrm{Pb}$ level, the higher the MDA level in spermateka.

The results of the highest $\mathrm{Pb}$ heavy metal values in the kamal area are $110.40 \mathrm{mg} / \mathrm{kg}$ and the highest MDA content in vesicles see Fig. 1 below.

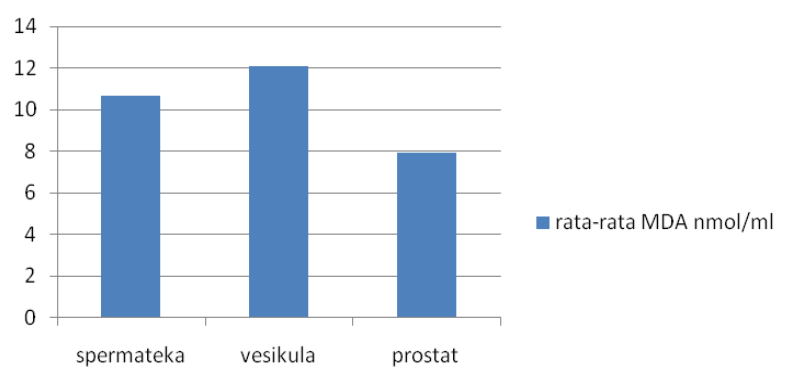

Fig. 2. The composition of MDA in M Postuma

Spermateka is a part of female reproductive organs that is useful for temporarily storing sperm (8), and in this worm has three pairs of sperm if the higher the metal content of $\mathrm{Pb}$ in the soil, the accumulation of $\mathrm{Pb}$ metal into the body of the worm is greater so it will increase lipid levels in the cell and the cell is damaged. Tissue in the body of earthworms has a molecular damage that is not too severe because the content of MDA levels is still below $20 \mathrm{nmol} / \mathrm{ml}$. The MDA content standard was obtained from the results of Gao's research, Chao [9] which showed that earthworms with various kinds of heavy metal experiments in the control group had MDA levels below 20 $\mathrm{nmol} / \mathrm{ml}$. So it can be concluded that normal MDA levels are not more than $20 \mathrm{nmol} / \mathrm{ml}$. Whereas from the results of the analysis showed that the body of the worm had molecular damage ranging between 7.9-19.5 $\mathrm{nmol} / \mathrm{ml}$. this shows that there are strengths of earthworm tissue in heavy metal polluted $\mathrm{Pb}$ habitats.

\section{CONCLUSION}

This study concludes that there is a correlation between the weight of $\mathrm{Pb}$ in the MDA content in the spermatic part of the body and the highest MDA content in the vesicles. But this MDA content is still relatively normal. The suggestion of this research is to increase sampling on other types of earthworms which also have the potential as bioindicators and to experiment with other ROS tests.

\section{ACKNOWLEDGMENT}

Thank you to the Department of Biology and the Mathematic and Scientific Faculty which has given the opportunity to get a grant in 2017. 


\section{REFERENCES}

[1] W. Budijastuti, "Jenis cacing tanah yang berpotensi sebagai kandidat bioindikator logam $\mathrm{Pb}$ dan $\mathrm{Cr}$ berdasarkan kelimpahan, struktur morfometri dan kandungan sistein". Disertasi. Universitas Airlangga. http://www.lib.unair.ac.id/index.php?lang=id. 2016.

[2] W. Budijastuti, S. Hariyanto, and A. Soegianto, The specific species pattern of earthworms in contamined area with heavy metals. Am. Pub. Scie. vol. 2, 2017.

[3] R. Panday, P. S. Bhatt, T. Bhattarai, K. Shakya and Lakshmaiah, "Aldehyde dehydrogenase expression". BMC Res Notes vol. 9, p491, 2016.

[4] S. Singh, J. Singha, P. V. Adarsh, "Earthworm as ecological engineers to change the physico-chemical properties of soil: Soil vs vermicast". Ecological Eng., vol. 90 pp.1-5, 2016.
[5] J. Das, L. Bora, P. Goswami, P. Bhattacharyya, M. Raul and Kumar, "Vermiremediation of water treatment plant sludge employing metaphire posthuma: A soil quality and metal solubility prediction approach. Ecological Eng. Vol. 81 pp. 200-206, 2015.

[6] B. Rob. "Cosmopolitan Earthworms - an EcoTaxonomic Guide to the Peregrine Species of the World (4th edition). Canberra: VermEcology, 2010, pp. 100-102.

[7] Z. Wei, K. Liu, J. Li, J. Liang and K. Lin, "Impacts of BDE209 addition on $\mathrm{Pb}$ uptake, subcellular partitioning and gene toxicity in earthworm (Eisenia fetida)". J. of Hazardous Materials vol. pp. 737-744, 2015.

[8] J.R. Blakemore, "Checklist of Megadrile Earthworm (Annelida :Oligochaeta) Form Tamil Nadu, South India”. COE Fellow, Soil Ecology Group, YNU, Yokohama, Japan, 2010, pp. 50-56.

[9] N.L. Chao, "Earthworms and soil pollution". Thesis. Centre for Environmental Policy, Imperial College London, 2009, pp. 65-68. 